\title{
Obituary
}

\section{In Memory of Dr. Stede}

Dr. W. Stede, the widely known scholar and co-editor of the PaliEnglish Dictionary, passed away last year, leaving myself and his many friends grief-stricken at this loss.

My first meeting with Dr. Stede was in the early summer of 1924; this was the year following the devastating earthquake of Tokyo and this was also the period of calm following the First World War. I was then a young student, a graduate of the Indian Philosophy Department of Tokyo University, and like many students in Japan at that time, I was selected for studies abroad. Dr. Junjiro Takakusu, then a professor in the Sanskrit Literature Dept., discouraged me from my original choice of studying in Germany, and thereupon, I decided instead to go to England. And through Professor T. Kimura, I was referred to Dr. Stede, who was then residing in London.

Arriving in England, I purchased a map and somehow managed to find the Professor's residence at No. 277 Valley Road, along the quiet Stretham St. in the suburbs of the city. Dr. Stede and his wife received me with unforgettable kindness and warmth, and offered me a room in their own home.

I was very grateful and considered myself fortunate indeed to have been offered such accomodations, for the surrounding atmosphere was ideal for study and the view from the window, I remember, was very pleasant. In addition, during the year and a half of my stay in their home, in every way the Stede family - the Professor, Mrs. Stede, and their young daughter, Dorothy-treated me as a member of the family, making me a part of their daily life.

My days were mostly spent in studies at home or at the British Museum, where I had undertaken a research of the books, theses, and 
essays concerning Buddhism which had been written in the European languages. Dr. Stede, however, suggested that in addition to my own research, it would be profitable to study Pali, and he offered to tutour me twice a week in the reading of Pali texts. This gesture was revealing of the thoughtfulness of this man, for at that time, Dr. Stede was plagued with difficulties of his own; his painful case of asthma and the struggle to support his family of three as a lecturer at the London University.

Although his life was a hard one, it was apparent that his devotion to the study of the Pali-language and the satisfaction which he derived from that devotion, sustained him at such times. For watching him basking in the sun or listening to him make humorous comments on the passing scene, he seemed like a man at peace with himself, perfectly happy with his lot.

During the months I lived in Dr. Stede's home, many young students, who were in later years to become eminent scholars of Buddhism, came to visit the Professor. Among them were Dr. S. Miyamoto, Dr. E. Kanakura, Dr. R. Yamada, Dr. N. Tsuji, and even after I left London Dr. M. Nagai, Dr. R. Higata, Dr. B. Watanabe, and Dr. T. Sato were among those who came to live there. And through such associations and meetings, Dr. Stede contributed his share toward the development of the scholars of Buddhism and Indian Studies in Japan.

Thirty-five years have passed since I left the Stede home on Stretham St.; however, when I recall the kindness and guidance extended to me in those days by Dr. Stede, I can only feel grateful and at the same time, express my most profound feelings of condolence on the passing of Dr. W. Stede.

Hanayama Shinsho Professor of University of Tokyo 